\title{
Genetic diversity and extent of gene flow in the endangered Japanese population of Hodgson's hawk-eagle, Spizaetus nipalensis
}

\author{
SHIGEKI ASAI, YOSHIHIRO YAMAMOTO and SATOSHI YAMAGISHI
}

\section{Summary}

The Japanese subspecies of Hodgson's Hawk-eagle, Spizaetus nipalensis orientalis, is considered threatened and has been designated as Endangered by the Japanese government. We determined the complete mitochondrial DNA (mtDNA) sequence of this species and designed a primer set to amplify a highly variable region of mtDNA, part of the control region (CR), based on this complete sequence. Using the primers, we amplified the $\mathrm{CR}$ and then determined the haplotypes of 178 samples collected at different sites in Japan. A nested cladistic analysis indicated that gene flow within some clades was restricted. The inference key implied that isolation by distance had caused the restriction of gene flow. Moreover, the ranges of the clades in which restricted gene flow was detected overlapped with the ranges of other clades. These results suggest that there is no fragmental population of Hodgson's Hawk-eagle in Japan and that this species has dispersed within short distances, at least in some lineages. Genetic diversity was high in comparison with other species. Therefore, at least in terms of genetic diversity, the Japanese population of Hodgson's Hawk-eagle is probably not in a critical situation.

\section{Introduction}

Hodgson's Hawk-eagle, Spizaetus nipalensis orientalis, is a large raptor that inhabits montane forests with steep slopes (Morimoto and Iida 1992); it occurs mainly on the mainland of Japan (Honshu, Hokkaido, Shikoku and Kyushu) (Committee for Check-list of Japanese Birds 200o). This species is thought to be susceptible to human exploitation, including dam construction and deforestation, of mountain areas. On 31 August 2004, the Ministry of the Environment released a report that estimated the population of this raptor exceeds 1,800 individuals, and it has been designated as an Endangered species in the Red Data Book of Japan (Ministry of the Environment 2002). In addition, since 1993 the Japanese Government has also designated this species as "a national endangered species of wild fauna" based on the Law for the Conservation of Endangered Species of Wild Fauna and Flora. However, reports of systematic monitoring of the population or studies of its genetic structure have never been published in scientific journals. Therefore, little information is available on the population structure of this species.

Generally, it is assumed that genetic diversity in a diminished population of an endangered species is low due to genetic drift. A decline in genetic diversity would reduce the adaptability of a population to environmental fluctuation (Primack and Kobori 1997). It is therefore necessary to determine the genetic diversity to evaluate the current status of an endangered species. If areas of unsuitable habitat separate 
subpopulations (i.e. restricted gene flow) the population is considered Vulnerable even if the overall population maintains high genetic diversity. In South-east Asia, some species of Spizaetus have suffered from declines in population size and habitat fragmentation (e.g. Preleuthner and Gamauf 1998, van Balen et al. 2001). In smaller subpopulations that lack gene flow, minor alleles are more easily lost due to genetic drift, thereby reducing genetic diversity. Large-scale development accompanied by the destruction of montane forests may not only extinguish the habitat of the hawk-eagle but also constrain individual movements among local populations. Hence, it is very important to determine whether there is a local population that is likely to become isolated from other local populations through habitat destruction.

Given the ignorance of population structure in rare species, genetic studies of endangered species, including Hodgson's Hawk-eagle, must be conducted before development critically harms populations. Our aim was to reveal the extent of gene flow in Hodgson's Hawk-eagle so that future development projects can minimize their influences on this endangered raptor, and to determine whether the current population contains sufficient genetic diversity.

\section{Methods}

Determination of the complete $m t D N A$ sequence

The control region (CR) of mitochondrial DNA (mtDNA) is thought to be most appropriate for detecting intraspecific genetic variation due to its high variability (Baker and Marshall 1997). A primer set to amplify the CR is a prerequisite for genetic studies using the CR; therefore, it is necessary to sequence a region of mtDNA containing the $\mathrm{CR}$ in a preliminary experiment in order to design the primers (unlike the cytochrome $b$ region, for which universal primers can be used). We determined the complete DNA sequence of the mitochondrial genome of Hodgson's Hawk-eagle, Spizaetus nipalensis.

Total cellular DNA was extracted from blood of a Hodgson's Hawk-eagle. The complete 17,667 base pair (bp) nucleotide sequence of the mitochondrial genome of the hawk-eagle (Accession No. APoo8238) was determined using described procedures (Yamamoto et al. 2000). The 13 protein-coding mitochondrial genes and 22 transfer RNAs (tRNAs) were then identified by comparison with other avian mitochondria. In contrast to the gene order in Gallus gallus (R. Okimoto et al. unpublished), the CR of $S$. nipalensis is located between tRNA-thr and tRNA-pro. In S. nipalensis, at the position of the $\mathrm{CR}$ in many birds, a non-coding region (pseudo-CR) is found between tRNA-glu and tRNA-phe, as in other raptors, including Buteo buteo (Haring et al. 1999) and Falco peregrinus (Mindell et al. 1998). The mtDNA length (bp) in these raptors differs due to differences in the CR or pseudo-CR.

\section{DNA samples and determination of haplotypes}

From 1999 to 2003, feathers moulted from Hodgson's Hawk-eagles were collected in and around nests after the breeding season. DNA was extracted mainly from these feather samples and from muscle samples of carcasses that had been supplied as specimens to the Yamashina Institute for Ornithology, using a DNeasy Tissue Kit (QIAGEN) according to the manufacturer's guidelines. 
We designed a primer set (SnContRegFa 5'-ATT CTC TTC CCC CTA GTT GC-3' and SnContRegRa 5'-AGG ATT AAC CGA GTC ATG GC-3') to amplify a 685 bp fragment containing a highly variable part (domain I; defined as a $418 \mathrm{bp}$ region from the $5^{\prime}$-end of the CR to the $5^{\prime}$-adjacent site of the F box, a conserved sequence block in the CR), based on the complete mtDNA sequence. PCR was conducted with standard procedures using Ex Taq (TaKaRa) at an annealing temperature of $56^{\circ} \mathrm{C}$. Polymerase chain reaction (PCR) products were separated on $1 \%$ agarose gels (SeaKem LE agarose by BMA) and then purified by the phenol-chloroform procedure. Purified PCR products were sequenced using a BigDye Terminator (Applied Biosystems) with either the SnContRegFa or SnContRegRa primer following the manufacturer's recommendations. Sequence data were read with a 3100 Genetic Analyzer (Applied Biosystems).

The domain I region was trimmed from the sequence data. Multiple alignments of CR domain I sequence were performed using GENETYX in order to determine the haplotype of each sample.

\section{Procedure to distinguish feather samples of one individual from those of others}

In the field, after the residence of a hawk-eagle pair was confirmed, feather samples were collected at or near the nest. A collected feather could have been shed from a breeding male, breeding female or their chicks, although the individual that shed it was not identified in the field. As many as 17 feathers were collected from a particular nest. Genetic diversity and gene flow must be analysed using data on individual haplotypes. Since the haplotype of the mtDNA of chicks is the same as that of the mother, the haplotype of a feather would be derived from a breeding male or a breeding female. Therefore, a series of feather samples with the same haplotype was considered to be derived from one individual if the samples had been collected at or near a nest occupied by a pair.

This criterion may have misled us into judging that two samples with the same haplotype were derived from one individual, when they could actually have come from two individuals with the same haplotype. Hence, we may have underestimated the number of individuals, which in turn may have led to an overestimation of genetic diversity. Therefore, we included a second criterion: we considered that two or more feathers were always derived from both members of a pair even if only one haplotype was found in their samples. Moreover, if the samples were collected in different years, we considered another pair to have occupied the nest. This second criterion (maximum estimate) should overestimate the number of individuals. Consequently, the true value must lie between the results obtained using these two criteria.

\section{Haplotype analyses}

We did not hypothesize the presence of any barriers that restrict gene flow and attempted to exhaustively detect restrictions of gene flow. A nested cladistic analysis examines the range of a clade consisting of haplotypes united by a parsimonious algorithm (Templeton et al. 1987, Templeton 1998). It allows us to examine the extent of gene flow under no hypothesis, because it does not need to define arbitrary subpopulations to which each sample is attributed. This method examines geographical distances between and within clades in a cladogram based on statistical parsimony (Templeton et al. 1992) rather than genetic differentiation between arbitrary subpopulations. 
Before the nesting procedure, we constructed a haplotype phylogenetic tree with parsimony of mutation (Templeton et al. 1992, Templeton 1998). In the haplotype tree, tip haplotypes linked to an interior haplotype within a one-step mutation were nested in one clade according to the nesting algorithm described by Templeton et al. (1987). The haplotype tree was constructed and the nesting procedure performed with TCS 1.13 (Clement et al. 2000; TCS 1.18 was also used in some cases).

The geographical distances (clade distance and nested clade distance) were calculated according to Templeton et al. (1995). The clade distance represents an average distance from the geographical centre of the clade members, i.e. the extent of the clade range. The nested clade distance represents an average distance from the geographical centre of the clade members including other clades nested at a one-step higher level, i.e. the average distance from other nested clades.

Geographical distances and statistical tests were calculated using GeoDis 2.2 (Posada et al. 2000), inputting the latitude and longitude data (in minutes) of the location of the municipal offices in cities where the samples had been collected. Since the location information for three samples was for the prefecture only, coordinates of the approximate centre of each prefecture were used for these samples.

We were unable to determine a consistent evolutionary history among haplotypes from the data, so we could not determine which haplotype was an ancestral node in the network. Since we could not examine whether a tip clade was younger than an interior clade, we used the following criterion described by Templeton et al. (1995) to determine interior or tip clades: an interior clade is connected to the remainder of the network through two or more connecting branches and a tip clade is connected to the remainder of the network through only one connecting branch.

The association with a nested clade and the geographical distance was tested statistically. This test examines whether clades are distributed randomly across locations. When significance is detected, it is necessary to interpret which process resulted in the biased distribution of clades. Historical phenomena, such as fragmentation, range expansion and isolation by distance, would bias the distribution of clades (Templeton et al. 1995). The developers of the nested cladistic analysis provide an inference key to interpret biased distributions, based on significant distances and clade ranges, and they strongly encourage its use. We interpreted significance according to the inference key provided by GeoDis 2.2 (Posada et al. 2000).

Gene diversity ( $h$; Nei 1973) and nucleotide diversity ( $\pi$; Nei and Tajima 1981) were calculated using Arlequin 2.0 (Schneider et al. 2000), to examine whether the current population showed sufficient genetic diversity. In addition, the frequency of pairwise differences was plotted (mismatch distribution), and goodness-of-fit for the sudden expansion model (Rogers and Harpending 1992) was tested with Arlequin, which uses the method of Schneider and Excoffier (1999).

\section{Results}

Samples for which haplotypes were determined

Since feather samples were collected from nests or from the ground around nests, the DNA may have been damaged. Consequently, we were able to amplify the target fragment in $70 \%$ (178) of the samples. Sixty-nine individuals were identified from these 178 samples based on information about the haplotype and sampling site. As the 


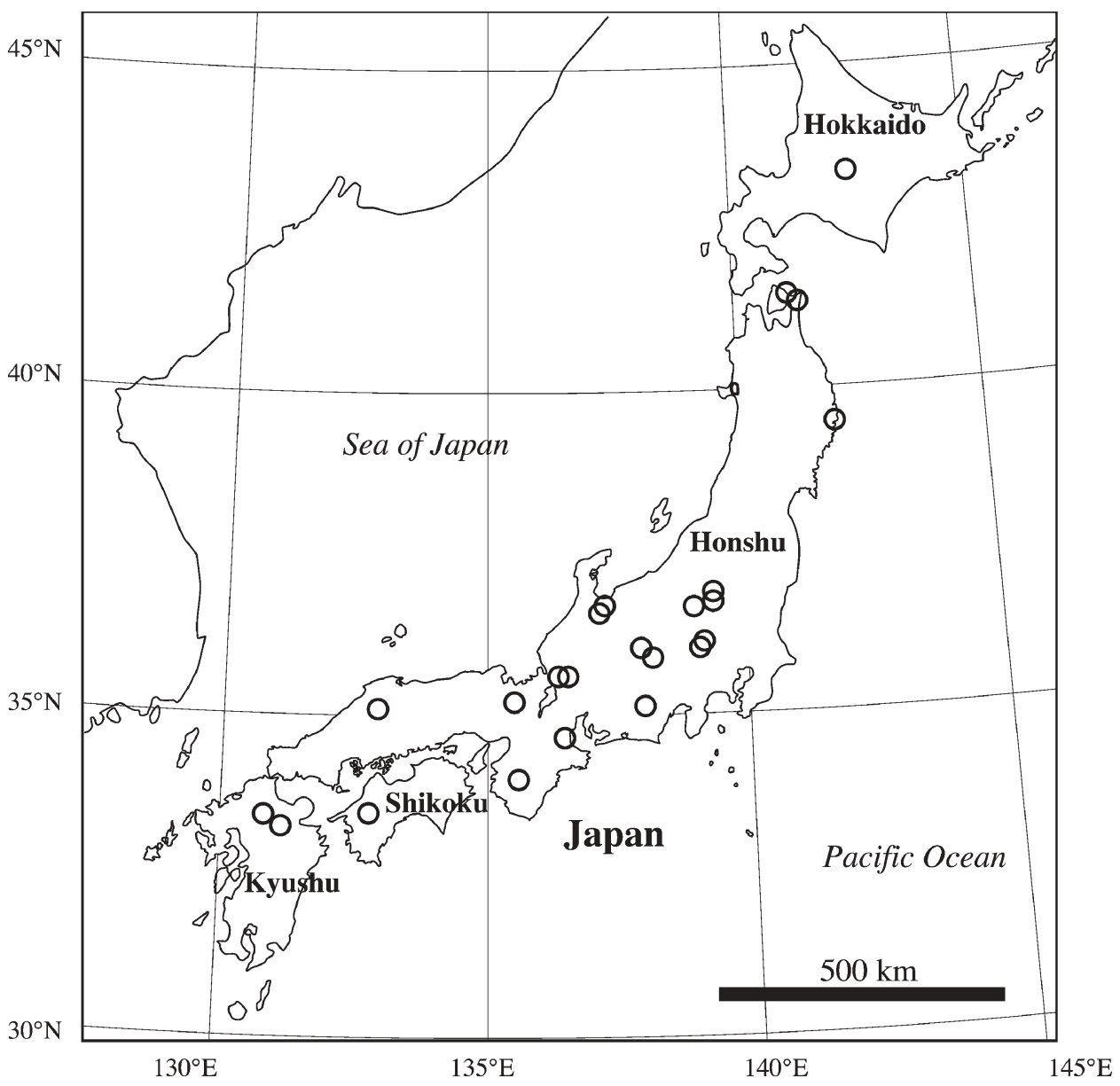

Figure 1. Sampling area. Open circles indicate the sampling sites.

maximum estimate, 93 individuals were identified. These individuals were sampled at 23 sites $\left(130^{\circ} 40^{\prime}-142^{\circ} 30^{\prime} \mathrm{E}, 33^{\circ} 15^{\prime}-43^{\circ} 30^{\prime} \mathrm{N}\right.$; Figure 1). Among the successfully amplified samples, we identified 25 haplotypes and one heteroplasmy that was excluded from the following analyses (Figure 2).

\section{Nested cladistic analysis}

The haplotype network of a population that has recently colonized should appear as a star-like network connected to an ancestral node within one or a few branches (mutations). In contrast, the observed haplotype network was broader than a typical star-like network (Figure 3).

Because it is possible to connect two haplotypes via several mutational process in the calculations, some closed loops occurred in the network. Although one of these connections was the true evolutionary process and the others were homoplasies, we could not identify the true evolutionary branch. Therefore, for many clades, we were unable to determine which was a tip and which was an interior clade. 


\begin{tabular}{|c|c|c|c|c|c|c|c|c|c|c|c|c|c|c|c|c|c|c|c|c|c|c|}
\hline \multirow[b]{2}{*}{ Haplotype } & \multicolumn{22}{|c|}{ Site } \\
\hline & $\begin{array}{l}3 \\
6\end{array}$ & $\begin{array}{l}5 \\
1\end{array}$ & $\begin{array}{l}6 \\
0\end{array}$ & $\begin{array}{l}7 \\
1\end{array}$ & $\begin{array}{l}7 \\
8\end{array}$ & $\begin{array}{l}8 \\
8\end{array}$ & $\begin{array}{l}1 \\
0 \\
7\end{array}$ & $\begin{array}{l}1 \\
1 \\
0\end{array}$ & $\begin{array}{l}1 \\
1 \\
7\end{array}$ & $\begin{array}{l}1 \\
9 \\
2\end{array}$ & $\begin{array}{l}2 \\
2 \\
4\end{array}$ & $\begin{array}{l}2 \\
5 \\
3\end{array}$ & $\begin{array}{l}2 \\
5 \\
8\end{array}$ & $\begin{array}{l}2 \\
7 \\
0\end{array}$ & $\begin{array}{l}2 \\
8 \\
3\end{array}$ & $\begin{array}{l}2 \\
9 \\
7\end{array}$ & $\begin{array}{l}3 \\
0 \\
5\end{array}$ & $\begin{array}{l}3 \\
8 \\
1\end{array}$ & $\begin{array}{l}4 \\
0 \\
0\end{array}$ & $\begin{array}{l}4 \\
0 \\
7\end{array}$ & $\begin{array}{l}4 \\
1 \\
5\end{array}$ & $\begin{array}{l}4 \\
1 \\
6\end{array}$ \\
\hline 1 & $\mathrm{~T}$ & G & $\mathrm{T}$ & $\mathrm{C}$ & $\mathrm{C}$ & - & $\mathrm{C}$ & A & G & A & G & $\mathrm{C}$ & $\mathrm{C}$ & A & $\mathrm{T}$ & $\mathrm{T}$ & $\mathrm{C}$ & $\mathrm{T}$ & G & $\mathrm{T}$ & A & A \\
\hline 2 & . & . & . & . & - & . & . & . & . & . & . & . &. & . & . & . & $\cdot$ & . & . & . &. & . \\
\hline 3 & . & . & . & . & . & . & . & . & . & . & . & $\cdot$ & . & . & . & . & . & . & A & . & . & $\cdot$ \\
\hline 4 & . & . & . & . & . & . & . & . & . & . & . & $\cdot$ & $\mathrm{T}$ & . & . & C & . & . & A & . & . & $\cdot$ \\
\hline 5 & . & . & . & . & . & . & . & . & . & . & . & $\cdot$ & . & . & . & C & $\mathrm{T}$ & . & A & . & . & $\cdot$ \\
\hline 6 & . & . & . & . & . & . & . & . & . & . & . & . & . & . & . & C & . & . & A & . & . & . \\
\hline 7 & $\mathrm{C}$ & . & . & $\mathrm{T}$ &. & . & . & . & . & . & . & . &. & . & . & C & . & . & A & . & . & $\cdot$ \\
\hline 8 & . & . & . & . & - & . & . & . & . & . & . & . & . & . & . & C & . & . & A & . & . & $\cdot$ \\
\hline 9 & . & . & . & . & - & . & . & . & A & . & . & . & . & . & . & C & . & . & A & . & . & . \\
\hline 10 & . & . & . &. &. & . & . & . & A & . & A & $\cdot$ & $\mathrm{T}$ & $\mathrm{G}$ & . & C & . & C & A & . & . & G \\
\hline 11 & . & . & . & $\mathrm{T}$ & . & . & . & . & . & . & . & . & . & . & . & C & . & . & A & . & . & . \\
\hline 12 & . & . & . &. & - & . & . & . & . & . & . & . & . & $G$ & . & C & . & . & A & . & . & $\cdot$ \\
\hline 13 & . & . & . & . & $\mathrm{T}$ & 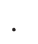 & . & . & A & . & . & . & . & . & . & C & . & . & A & . & $\mathrm{G}$ & . \\
\hline 14 & . & . & . & . & . & . & . & . & A & . & . & $\cdot$ & . & . & . & C & . & . & A & . & $\mathrm{G}$ & $\cdot$ \\
\hline 15 & . & . & . & . & - &. & . & . & A & . & 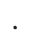 & . &. & . & . & C & . & . & A & . & G & . \\
\hline 16 & . & . & . & . & - & . & $\mathrm{T}$ & 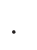 & . & G & & . & . & $\mathrm{G}$ & . & C & 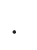 & . & A & & . & . \\
\hline 17 & . & A & A & . & . & . & . & . & . & . & 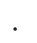 & . & . & $\mathrm{G}$ & . & C & . & . & A & . & . & . \\
\hline 18 & . & . & . & . & . & . & . & . & . & G & . & . & . & $\mathrm{G}$ & C & C & . & . & A & . & . & $\cdot$ \\
\hline 19 & . & . & . & . & . & . & . & . & . & . & . & . & . & $\mathrm{G}$ & . & C & . & . & A & . & . & . \\
\hline 20 & . & . & . & . & . & . & . & $\mathrm{G}$ & . & . & . & . &. & . & . & C & . & . & A & . & . & $\cdot$ \\
\hline 21 & . & . & . & . & - & . & . & . & . & . & $\cdot$ & . & . & . & . & . & . & - & A & - & . & $\cdot$ \\
\hline 22 & . & . & . & . & - & . & . & . & . & . & . & . & . & . & . & . & . & . & A & . & . & . \\
\hline 23 & . & . & . & . & - & 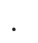 & . & . & . & $\mathrm{G}$ & & 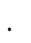 & . & $\mathrm{G}$ & $\mathrm{C}$ & C & . & . & A & & . & . \\
\hline 24 & . & . & . & . & - & . & . & . & $\mathrm{R}$ & . & . & . & . & $\cdot$ & . & C & . & . & A & . & . & . \\
\hline 25 & . & . & . & . & - & . & . & . & . & . & & T & . & . & . & . & . & . & A & & . & \\
\hline 26 & . & . &. & & . & C & & & & & & & . & & & C & & . & A & & . & \\
\hline
\end{tabular}

Figure 2. Variable sites of 25 haplotypes and one heteroplasmy (no. 24) in Hodgson's hawkeagle. Dots indicate identity with the top sequence (haplotype 1 ). " $R$ " represents either an adenine base or a guanine.

In the nesting procedures, haplotypes/nodes were nested to I4 clades at the onestep clade level, and those one-step clades were nested to six clades at the two-step level; finally, the two-step clades were nested to two clades at the three-step level (Figure 3). Nested contingency tests in which sampling localities were treated as categorical variables (Templeton et al. 1995) indicated that the geographical association among the clades nested in clade $3-2$ was significant $\left(\chi^{2}=49.72, P=0.036\right)$. For the maximum estimate, the tests indicated that the associations in clades $2-6$ and $3-2$, and the total cladogram, were significant $\left(\chi^{2}=26.07, P=0.023 ; \chi^{2}=52.97, P=0.014\right.$; $\chi^{2}=37.96, P=0.002$, respectively).

Table 1 shows clade distances and nested clade distances. The leftmost column indicates the haplotype number, and for each haplotype we calculated a clade distance (Dc; second column) and a nested clade distance (Dn; third column). Haplotypes 5, 6, 20 and 26 were nested in clade $1-1$ according to the nesting algorithm (Figure 3 ), and then each haplotype was defined as either a tip (T) or an interior (I) clade within clade 


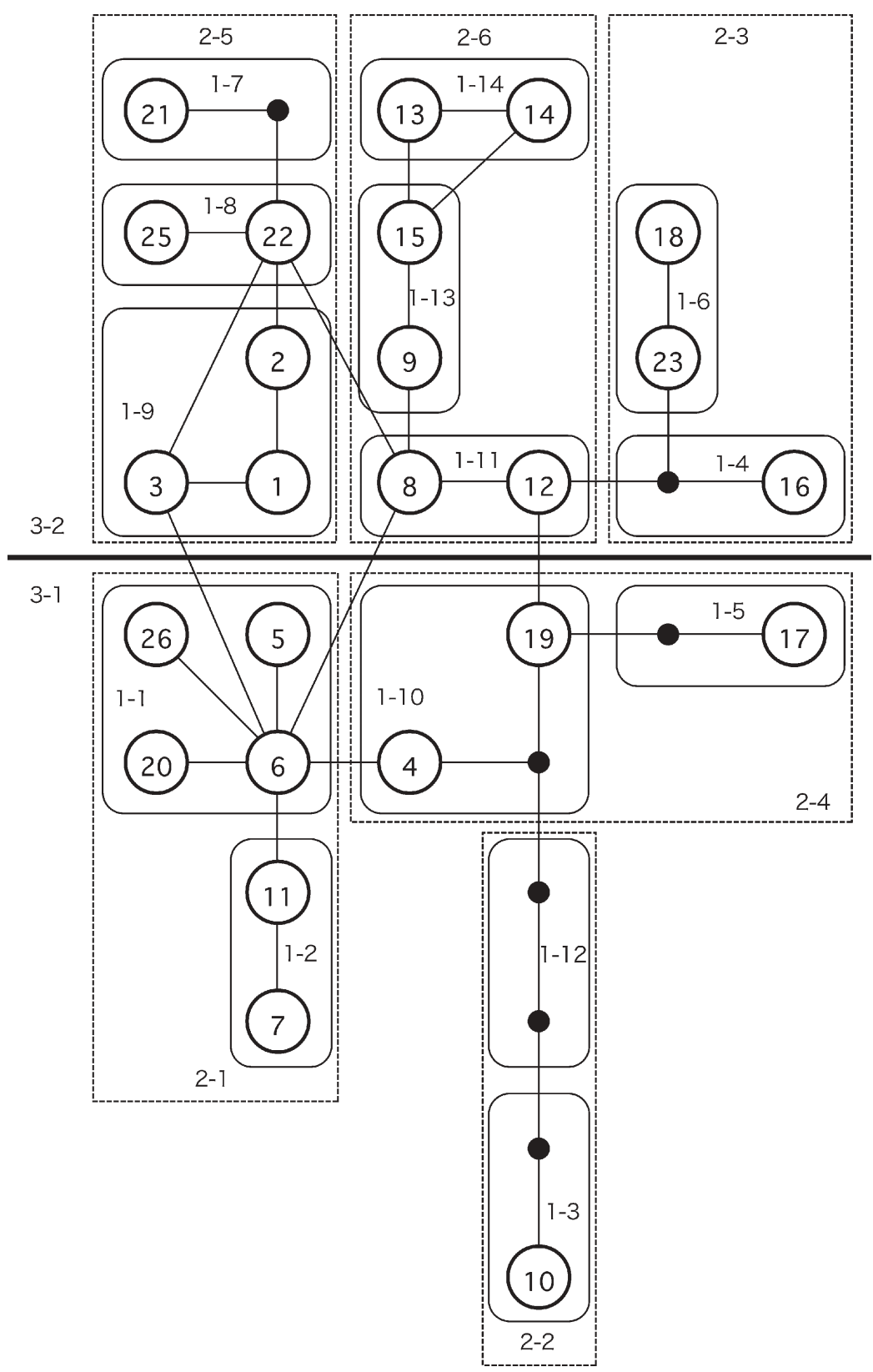

Figure 3. Haplotype network with the nesting design. Open circles with figures and lines represent haplotypes and one-step mutations. The figures in the circles indicate haplotype number and correspond to those in the appendices. Small circles represent haplotypes not found in this study. Rectangles with rounded corners and rectangles with broken lines represent clades at the one- and two-step levels, respectively, and the clade number enclosed in these rectangles corresponds to Table 1 . At the three-step level, clades are divided into an upper side (3-2) and a lower side $(3-1)$ by a thick line. 


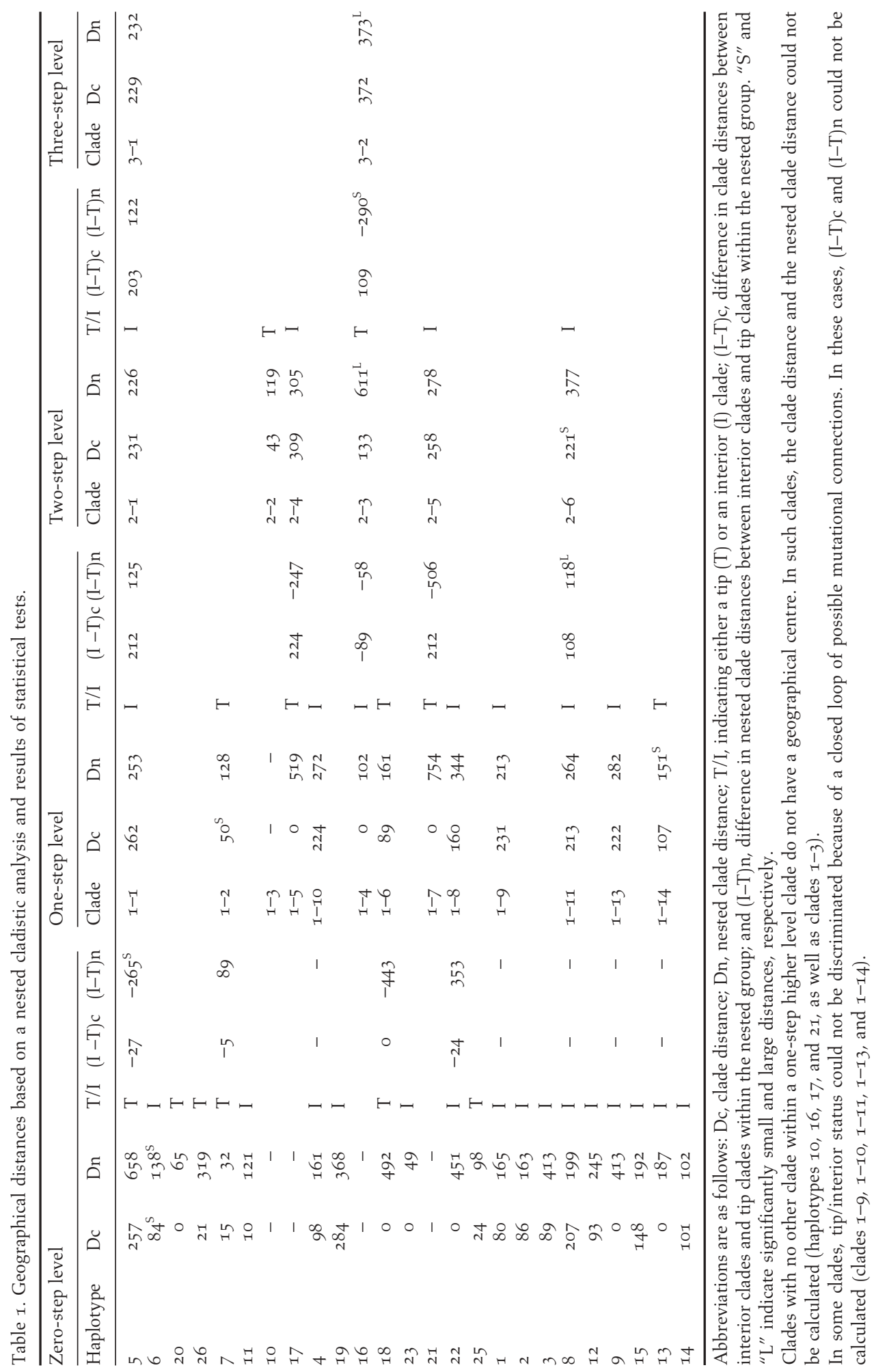




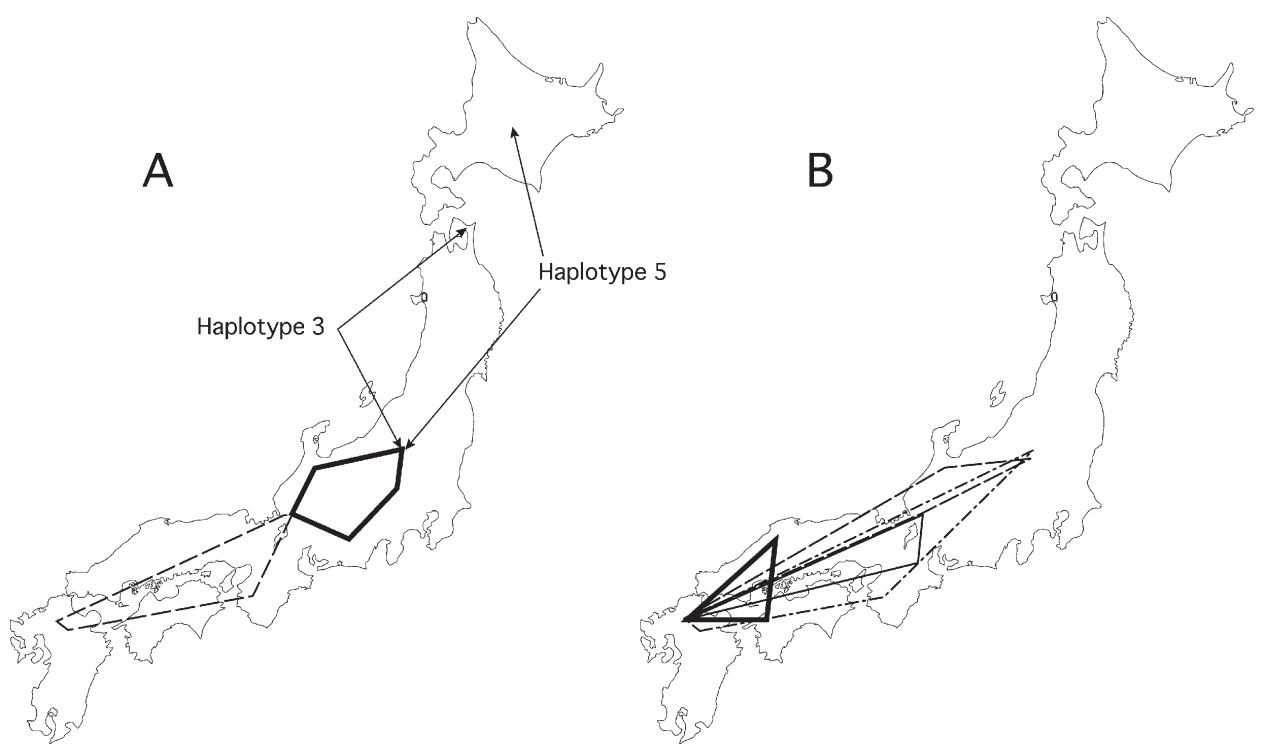

Figure 4. Ranges of haplotypes $(A)$ and clades at level $I(B)$. In these figures, some typical examples are indicated by polygons tracing the outermost sampling sites. In $(A)$, thick lines and broken lines represent the range of haplotypes 6 and 8, respectively. Haplotypes 3 and 5 were found at two sampling sites (indicated by arrows). In $(B)$, thick lines, thin lines, broken lines, and dotted and broken lines represent the ranges of clades $1-14,1-8,1-10$, and $1-11$, respectively. Although statistically significant geographical distances in haplotype 6 and clade 1-14 indicate that gene flow of these clades was restricted within the clades nesting those clades, the ranges were overlapped by those of the other clades rather than being separated from the others.

1-1 (the fourth column). When either a tip or an interior could be defined, we could calculate the difference between the average of the interiors and tips for the clade distances ([I-T]c in the fifth column) and for the nested clade distances ([I-T]n in the sixth column). At the one-step level, clade I-1 replaces haplotypes 5, 6, 20 and 26 in the seventh column. Again, Dc, Dn, T/I, (I-T)c and (I-T)n could be given for the one-step clade, in the five columns on the right. Those procedures are repeated at the two- and three-step levels.

Dc and Dn of haplotype 6 were significantly smaller than the values for other haplotypes within clade $1-1$, indicating that the distribution of clade $1-1$ was biased or that gene flow within clade $1-1$ was restricted. In clades $1-1,2-1,2-6,3-2$, and the total cladogram, one or more distances were significant, indicating that gene flow was restricted within these clades. However, the ranges of clades with restricted gene flow were not separated from those of the other clades without restriction, but rather overlapped each other (Figure 4). Therefore, we could not find evidence that a local population of Hodgson's hawk-eagle is geographically isolated from other populations in Japan. The inference key implied that the detected restriction of gene flow was due to isolation by distance rather than fragmentation of a local population. However, this inference does not mean that the dispersal ability of this species is physically small.

For the maximum estimate, one or more distances were significant in clades $1-2$ and $1-9$, in addition to the above-mentioned clades. Nevertheless, the inference key could not provide an interpretation because the sampling design was insufficient. 


\section{Genetic diversity}

We calculated the indices of genetic diversity for 68 individuals. Gene diversity $(h)$ and nucleotide diversity $(\pi)$ were $0.943 \pm 0.014$ SD and $0.702 \pm 0.413$ SD \%, respectively. These indices indicate that maternal lineages differed from each other among more than $90 \%$ of pairs of two individuals sampled randomly from the Japanese population, and on average randomly sampled pairs differed from each other in three of $418 \mathrm{bp}$ in the CR. The indices calculated using the maximum estimate (91 individuals) were $h=0.935 \pm 0.013 \mathrm{SD}$ and $\pi=0.741 \pm 0.430 \mathrm{SD} \%$. Even when the indices were calculated from 174 samples instead (heteroplasmy was found in four samples), ignoring the overlap of individuals, the gene diversity and nucleotide diversity were $0.913 \pm 0.009 \mathrm{SD}$ and $0.710 \pm 0.413 \mathrm{SD} \%$, respectively.

The distribution of pairwise differences (mismatch distribution) was unimodal, and fitted the sudden expansion model (model parameters: $\tau=2.923, \theta_{0}=0.000, \theta_{1}=$ 2890.000; in case of the maximum estimate, $\tau=2.803, \theta_{0}=0.262, \theta_{1}=37.676$, unimodal). A second wave of larger values of pairwise differences would suggest a bottleneck (Rogers and Harpending 1992); however, in the observed distribution, no second wave was found. Therefore, the Japanese population was assumed to have expanded, having experienced no bottlenecks since colonization.

\section{Discussion}

\section{Genetic structure}

The presence of a barrier that restricts individual movements would result in two or more clades whose ranges are limited to a particular area. In this study, the ranges of the clades for which restricted gene flow was detected overlapped with the ranges of other clades. Moreover, the inference key implied that the detected restrictions of gene flow were due to isolation by distance rather than by fragmentation. Therefore, there is no suggestion that the Japanese population of Hodgson's Hawk-eagle has been separated geographically in the process of range expansion. Nevertheless, because it takes several generations for habitat fragmentation to result in a change in the genetic structure, the results may not reflect geographical fragmentation occurring in the recent past.

Gene flow was restricted in some clades, however. Although the restricted gene flow was implied to be the result of isolation by distance, the dispersal ability of this species is not thought to be so limited that it cannot disperse physically beyond the small clade ranges, because the clade distances of the lowest level, haplotypes 5 and 19, were larger (Table I). Moreover, records indicate that this species has wandered from Japan to Korea (Austin 1948), which indicates the potential of long-range dispersal in this species. Consequently, it is thought that the range expansion of some lineages is limited by factors other than geography. Instead, ecological or behavioural factors are expected to limit range expansion. Unfortunately, we have little information on dispersal in Hodgson's Hawk-eagle. Since this species is considered sedentary and its breeding dispersal slight, although some move seasonally to lower altitudes in India and Nepal (Ali and Ripley 1978, Brazil 1991, Grimmett et al. 1998, Inskipp and Inskipp 1991, Morioka et al. 1995), natal dispersal is relatively important for range expansion. In Japan, it has been observed that fledglings remain in the home 


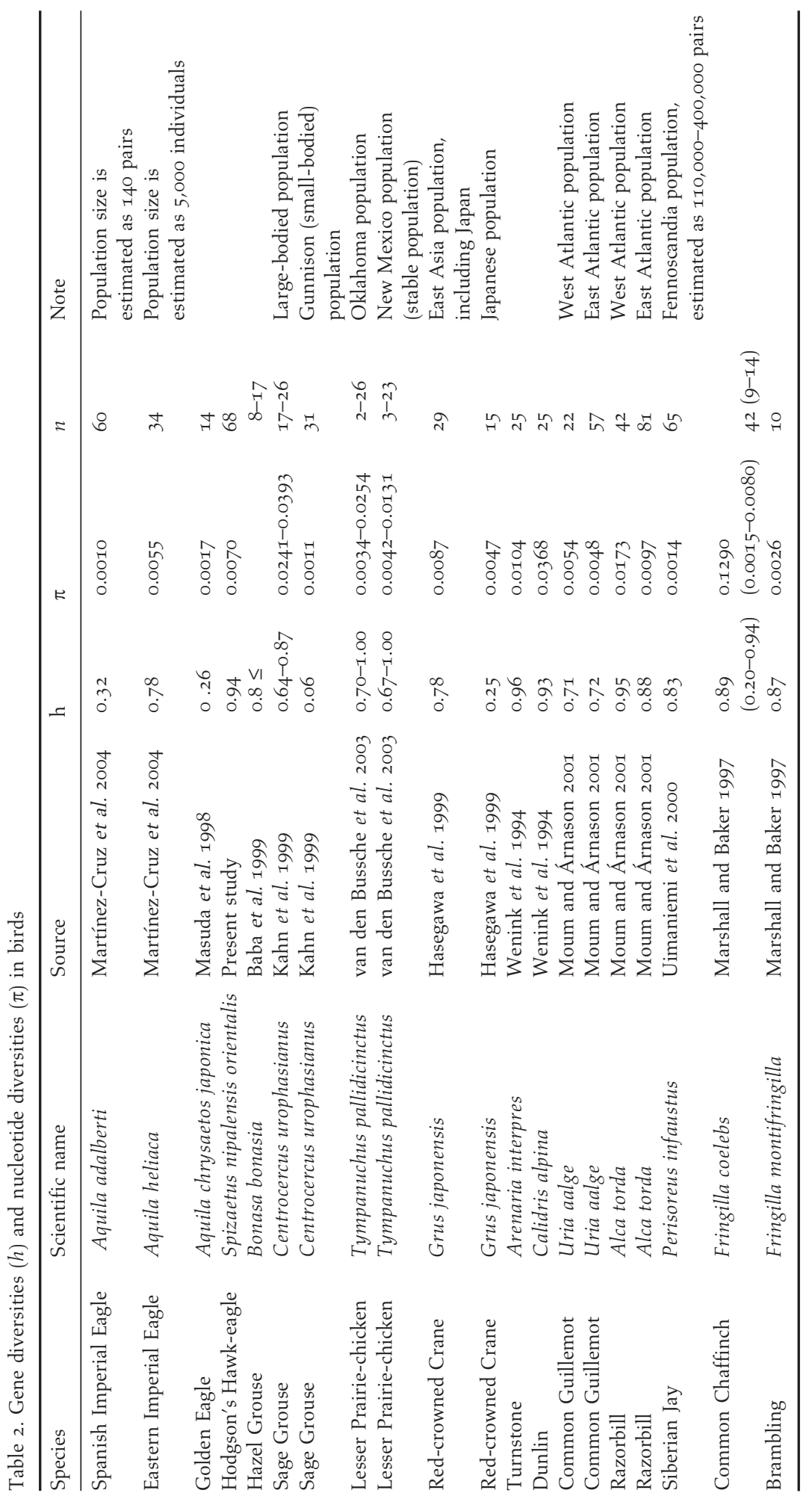


ranges of their parents for 2-3 years (Inoue 2000, Yamazaki 2000). In addition, of two individuals considered sub-adults based on their iris colours that carried radiotransmitters for 16 months, one was observed to mate while wandering over $42.7 \mathrm{~km}^{2}$, and the other did not leave the mountains where it had been trapped, although it wandered more widely (within $135.5 \mathrm{~km}^{2}$; Murate 2000). These observations imply that natal dispersal of the Hodgson's Hawk-eagle is also relatively small. In contrast, juveniles and immatures of the Javan Hawk-eagle, Spizaetus bartelsi, disperse to different habitats from where the adults breed (Nijman and van Balen 2003). This implication corresponds to the fact that the ranges of some clades are small. However, it is not possible to state that the ranges of some clades are significantly smaller than those of others. To resolve this problem, it is necessary to collect data on natal dispersal and differences in local habitats. In addition, it is important to increase the sample size for the analysis used in this study in order to detect exactly where gene flow is restricted.

\section{Genetic diversity}

The genetic diversity of this species is nearly equal to or higher than that of other species (populations), including the Eastern Imperial Eagle Aquila heliaca, Turnstone Arenaria interpres, Dunlin Calidris alpina, Atlantic populations of Common Guillemot Uria aalge and Razorbill Alca torda, Common Chaffinch Fringilla coelebs and Brambling Fringilla montifringilla (Table 2), which maintain sufficient numbers of individuals and are not considered threatened. In contrast, the genetic diversities of the Spanish Imperial Eagle Aquila adalberti, Japanese populations of the Golden Eagle Aquila chrysaetos japonica and Red-crowned Crane Grus japonensis, Sage Grouse Centrocercus urophasianus, New Mexico populations of the Lesser Prairiechicken Tympanuchus pallidicinctus, and the Siberian Jay Perisoreus infaustus, which are endangered owing to declining populations or habitat fragmentation, are lower (Table 2). Therefore, our results suggest that a sufficient number of maternal lineages have been maintained in the extant Japanese population of Hodgson's Hawk-eagle.

The nucleotide diversity of Hodgson's Hawk-eagle is higher than those of the above fragmented populations, except for grouse (Table 2). This indicates that a relatively large number of old lineages has been retained, because nucleotide diversity reflects time since divergence. This corresponds to the lack of evidence for a bottleneck observed in the mismatch distribution.

Since feathers, which were the main source of samples in our study, were collected in the field, individuals were identified based on their haplotypes and the site where the feathers were collected. Although this criterion may have misled us, the values calculated from the maximum estimate and the total number of samples were similar to the values calculated based on 68 individuals identified, and were still high in comparison to other species.

\section{Status of Hodgson's Hawk-eagle}

At least in terms of genetic diversity, the Japanese population of Hodgson's Hawkeagle is not likely to require urgent attention; moreover, it does not appear to have experienced a critical bottleneck situation in the past. The high genetic diversity is unlikely to result from occasional immigration from South-east Asian populations, 
because the haplotypes identified in this study were connected to subsequent haplotypes within one or two mutations, except for haplotype 10. If there was gene flow between Japan and mainland Asia, more long branches would have been found in the haplotype network, and the mismatch distribution would have been multimodal.

If there is no immigration into the Japanese population and no regular longdistance dispersal, it may be difficult for this species to recolonize the range that it once occupied. To address this question, ecological studies of dispersal are needed.

The genetic diversities of Japanese populations of the Red-crowned Crane and Golden Eagle, which are large birds, are much lower than that of the hawk-eagle (Table 2). In the Red Data Book of Japan, the Red-crowned Crane and Golden Eagle are ranked as Vulnerable and Endangered, respectively, while the hawk-eagle is considered Endangered. The populations of the former two species are definitely smaller (750 and 500 individuals, respectively; Ministry of the Environment 2002) than that of the hawk-eagle. Therefore, genetic diversity does not necessarily correspond to the status assigned in the Red Data Book. Since protection programmes should be implemented after considering genetic diversity and structure, genetic studies should also be conducted for the other endangered species.

Appendix 1. Haplotype and locality of identified individuals

Individual-Haplotype (Locality): $1-6\left(35^{\circ} 57^{\prime} \mathrm{N}, 138^{\circ} 56^{\prime} \mathrm{E}\right) ; 2-6\left(35^{\circ} 57^{\prime} \mathrm{N}, 138^{\circ} 56^{\prime} \mathrm{E}\right)$; 3-6 ( $\left.36^{\circ} \mathrm{OO}^{\prime} \mathrm{N}, 139^{\circ} \mathrm{O}^{\prime} \mathrm{E}\right) ; 4^{-15}\left(33^{\circ} 15^{\prime} \mathrm{N}, 130^{\circ} 58^{\prime} \mathrm{E}\right) ; 5^{-8}\left(33^{\circ} 15^{\prime} \mathrm{N}, 130^{\circ} 58^{\prime} \mathrm{E}\right)$; 6-6 ( $\left.36^{\circ} 42^{\prime} \mathrm{N}, 139^{\circ} 13^{\prime} \mathrm{E}\right) ; 7-21\left(33^{\circ} 25^{\prime} \mathrm{N}, 130^{\circ} 40^{\prime} \mathrm{E}\right) ; 8-17\left(33^{\circ} 25^{\prime} \mathrm{N}, 130^{\circ} 40^{\prime} \mathrm{E}\right)$; 9-8 ( $\left.33^{\circ} 25^{\prime} \mathrm{N}, 130^{\circ} 40^{\prime} \mathrm{E}\right)$; $10-13\left(33^{\circ} 25^{\prime} \mathrm{N}, 130^{\circ} 40^{\prime} \mathrm{E}\right)$; I1-14 $\left(33^{\circ} 25^{\prime} \mathrm{N}, 130^{\circ} 40^{\prime} \mathrm{E}\right)$; $12-22\left(33^{\circ} 25^{\prime} \mathrm{N}, 130^{\circ} 40^{\prime} \mathrm{E}\right) ; 13-19\left(33^{\circ} 25^{\prime} \mathrm{N}, 130^{\circ} 40^{\prime} \mathrm{E}\right) ; 14-14\left(35^{\circ} \mathrm{O} 5^{\prime} \mathrm{N}, 132^{\circ} 47^{\prime}\right.$ $\mathrm{E})$; $15-10\left(35^{\circ} 35^{\prime} \mathrm{N}, 136^{\circ} 27^{\prime} \mathrm{E}\right) ; 16-15\left(35^{\circ} 35^{\prime} \mathrm{N}, 136^{\circ} 27^{\prime} \mathrm{E}\right) ; 17-8\left(35^{\circ} 35^{\prime} \mathrm{N}, 136^{\circ} 27^{\prime}\right.$ E); $18-9\left(35^{\circ} 35^{\prime} \mathrm{N}, 136^{\circ} 27^{\prime} \mathrm{E}\right) ; 19-19\left(35^{\circ} 35^{\prime} \mathrm{N}, 136^{\circ} 27^{\prime} \mathrm{E}\right) ; 20-6\left(35^{\circ} 35^{\prime} \mathrm{N}, 136^{\circ} 27^{\prime}\right.$ E); $21-6\left(35^{\circ} 35^{\prime} \mathrm{N}, 136^{\circ} 27^{\prime} \mathrm{E}\right) ; 22-11\left(35^{\circ} 35^{\prime} \mathrm{N}, 136^{\circ} 27^{\prime} \mathrm{E}\right) ; 23-1\left(36^{\circ} 46^{\prime} \mathrm{N}, 139^{\circ} 14^{\prime}\right.$ E); $24-6\left(36^{\circ} 46^{\prime} \mathrm{N}, 139^{\circ} 14^{\prime} \mathrm{E}\right) ; 25-18\left(36^{\circ} 46^{\prime} \mathrm{N}, 139^{\circ} 14^{\prime} \mathrm{E}\right) ; 26-1\left(36^{\circ} 46^{\prime} \mathrm{N}, 139^{\circ} 14^{\prime}\right.$ E); $27-2\left(36^{\circ} 46^{\prime} \mathrm{N}, 139^{\circ} 14^{\prime} \mathrm{E}\right) ; 28-20\left(36^{\circ} 46^{\prime} \mathrm{N}, 139^{\circ} 14^{\prime} \mathrm{E}\right) ; 29-2\left(36^{\circ} 46^{\prime} \mathrm{N}, 139^{\circ} 14^{\prime}\right.$ E); 30-1 ( $\left.36^{\circ} 46^{\prime} \mathrm{N}, 139^{\circ} 14^{\prime} \mathrm{E}\right) ; 31-3\left(36^{\circ} 46^{\prime} \mathrm{N}, 139^{\circ} 14^{\prime} \mathrm{E}\right) ; 32-8\left(35^{\circ} 33^{\prime} \mathrm{N}, 136^{\circ} 12^{\prime} \mathrm{E}\right)$; 33-11 ( $\left.35^{\circ} 33^{\prime} \mathrm{N}, 136^{\circ} 12^{\prime} \mathrm{E}\right) ; 34^{-12}\left(35^{\circ} 33^{\prime} \mathrm{N}, 136^{\circ} 12^{\prime} \mathrm{E}\right) ; 35^{-12}\left(35^{\circ} 33^{\prime} \mathrm{N}, 136^{\circ} 12^{\prime}\right.$ $\mathrm{E}) ; 36-4\left(36^{\circ} 42^{\prime} \mathrm{N}, 139^{\circ} 13^{\prime} \mathrm{E}\right) ; 37^{-2}\left(36^{\circ} 42^{\prime} \mathrm{N}, 139^{\circ} 13^{\prime} \mathrm{E}\right) ; 38-5\left(36^{\circ} 42^{\prime} \mathrm{N}, 139^{\circ} 13^{\prime} \mathrm{E}\right)$; 39-12 ( $\left.35^{\circ} 56^{\prime} \mathrm{N}, 137^{\circ} 47^{\prime} \mathrm{E}\right) ; 4 \mathrm{O}-7$ ( $\left.35^{\circ} 56^{\prime} \mathrm{N}, 137^{\circ} 47^{\prime} \mathrm{E}\right) ; 41-7\left(35^{\circ} 48^{\prime} \mathrm{N}, 138^{\circ} \mathrm{O} 5^{\prime} \mathrm{E}\right)$; $42-6$ ( $\left.35^{\circ} 48^{\prime} \mathrm{N}, 138^{\circ} \mathrm{O}^{\prime} \mathrm{E}\right) ; 43-6\left(36^{\circ} 34^{\prime} \mathrm{N}, 138^{\circ} 5 \mathrm{O}^{\prime} \mathrm{E}\right) ; 44^{-14}\left(33^{\circ} 23^{\prime} \mathrm{N}, 132^{\circ} 39^{\prime} \mathrm{E}\right) ;$ $45^{-2}\left(36^{\circ} 27^{\prime} \mathrm{N}, 137^{\circ} \mathrm{O} 2^{\prime} \mathrm{E}\right) ; 46-4\left(36^{\circ} 27^{\prime} \mathrm{N}, 137^{\circ} \mathrm{O} 2^{\prime} \mathrm{E}\right) ; 47-6\left(36^{\circ} 27^{\prime} \mathrm{N}, 137^{\circ} \mathrm{O} 2^{\prime} \mathrm{E}\right) ;$ $4^{8-10}\left(36^{\circ} 27^{\prime} \mathrm{N}, 137^{\circ} \mathrm{O} 2^{\prime} \mathrm{E}\right) ; 49-5$ ( $\left.43^{\circ} 3 \mathrm{O}^{\prime} \mathrm{N}, 142^{\circ} 3 \mathrm{O}^{\prime} \mathrm{E}\right) ; 5 \mathrm{O}-6$ ( $\left.35^{\circ} \mathrm{O} 5^{\prime} \mathrm{N}, 137^{\circ} 49^{\prime} \mathrm{E}\right)$; 51-16 ( $\left.39^{\circ} 22^{\prime} \mathrm{N}, 141^{\circ} 54^{\prime} \mathrm{E}\right) ; 52-3\left(41^{\circ} 26^{\prime} \mathrm{N}, 140^{\circ} 52^{\prime} \mathrm{E}\right) ; 53^{-23}\left(41^{\circ} 24^{\prime} \mathrm{N}, 141^{\circ} 10^{\prime} \mathrm{E}\right) ;$ $54-2\left(36^{\circ} 35^{\prime} \mathrm{N}, 137^{\circ} 12^{\prime} \mathrm{E}\right) ; 55^{-1}\left(36^{\circ} 35^{\prime} \mathrm{N}, 137^{\circ} 12^{\prime} \mathrm{E}\right) ; 56-8\left(33^{\circ} 55^{\prime} \mathrm{N}, 135^{\circ} 30^{\prime} \mathrm{E}\right) ;$ $57-22\left(33^{\circ} 25^{\prime} \mathrm{N}, 130^{\circ} 40^{\prime} \mathrm{E}\right) ; 58-6\left(35^{\circ} 35^{\prime} \mathrm{N}, 136^{\circ} 27^{\prime} \mathrm{E}\right) ; 59-12\left(36^{\circ} 46^{\prime} \mathrm{N}, 139^{\circ} 14^{\prime} \mathrm{E}\right) ;$ $60-1\left(35^{\circ} 57^{\prime} \mathrm{N}, 138^{\circ} 56^{\prime} \mathrm{E}\right) ; 61-2\left(36^{\circ} 34^{\prime} \mathrm{N}, 138^{\circ} 50^{\prime} \mathrm{E}\right) ; 62-1\left(36^{\circ} 34^{\prime} \mathrm{N}, 138^{\circ} 50^{\prime} \mathrm{E}\right) ;$ 63-7 ( $\left.35^{\circ} 56^{\prime} \mathrm{N}, 137^{\circ} 47^{\prime} \mathrm{E}\right) ; 64-25\left(35^{\circ} 35^{\prime} \mathrm{N}, 136^{\circ} 27^{\prime} \mathrm{E}\right) ; 65-25\left(35^{\circ} 35^{\prime} \mathrm{N}, 136^{\circ} 27^{\prime} \mathrm{E}\right)$; 66-25 ( $\left.34^{\circ} 46^{\prime} \mathrm{N}, 136^{\circ} 18^{\prime} \mathrm{E}\right) ; 67-26\left(35^{\circ} 15^{\prime} \mathrm{N}, 135^{\circ} 28^{\prime} \mathrm{E}\right) ; 68-24\left(35^{\circ} 35^{\prime} \mathrm{N}, 136^{\circ} 27^{\prime}\right.$ E); 69-26 (35 $\left.33^{\prime} \mathrm{N}, 136^{\circ} 12^{\prime} \mathrm{E}\right)$. 
Appendix 2. Haplotype and locality of identified individuals in the maximum estimate

Individual-Haplotype (Locality): $1-6\left(35^{\circ} 57^{\prime} \mathrm{N}, 138^{\circ} 56^{\prime} \mathrm{E}\right) ; 2-6\left(35^{\circ} 57^{\prime} \mathrm{N}, 138^{\circ} 56^{\prime} \mathrm{E}\right)$; 3-6 ( $\left.35^{\circ} 57^{\prime} \mathrm{N}, 138^{\circ} 56^{\prime} \mathrm{E}\right) ; 4^{-6}\left(35^{\circ} 57^{\prime} \mathrm{N}, 138^{\circ} 56^{\prime} \mathrm{E}\right) ; 5^{-1}\left(35^{\circ} 57^{\prime} \mathrm{N}, 138^{\circ} 56^{\prime} \mathrm{E}\right)$; 6-1 ( $\left.35^{\circ} 57^{\prime} \mathrm{N}, 138^{\circ} 56^{\prime} \mathrm{E}\right) ; 7-6\left(36^{\circ} \mathrm{Oo}^{\prime} \mathrm{N}, 139^{\circ} \mathrm{O} 5^{\prime} \mathrm{E}\right) ; 8-6$ ( $\left.36^{\circ} \mathrm{Oo}^{\prime} \mathrm{N}, 139^{\circ} \mathrm{O} 5^{\prime} \mathrm{E}\right) ; 9-15$ $\left(33^{\circ} 15^{\prime} \mathrm{N}, 130^{\circ} 58^{\prime} \mathrm{E}\right)$; $10-8\left(33^{\circ} 15^{\prime} \mathrm{N}, 130^{\circ} 58^{\prime} \mathrm{E}\right)$; 11-6 ( $\left.36^{\circ} 42^{\prime} \mathrm{N}, 139^{\circ} 13^{\prime} \mathrm{E}\right) ; 12-6$ $\left(36^{\circ} 42^{\prime} \mathrm{N}, 139^{\circ} 13^{\prime} \mathrm{E}\right) ; 13^{-22}\left(33^{\circ} 25^{\prime} \mathrm{N}, 130^{\circ} 40^{\prime} \mathrm{E}\right) ; 14-21\left(33^{\circ} 25^{\prime} \mathrm{N}, 130^{\circ} 40^{\prime} \mathrm{E}\right)$; $15-17\left(33^{\circ} 25^{\prime} \mathrm{N}, 130^{\circ} 40^{\prime} \mathrm{E}\right) ; 16-8\left(33^{\circ} 25^{\prime} \mathrm{N}, 130^{\circ} 40^{\prime} \mathrm{E}\right) ; 17-13\left(33^{\circ} 25^{\prime} \mathrm{N}, 130^{\circ} 40^{\prime} \mathrm{E}\right)$; 18-14 ( $\left.33^{\circ} 25^{\prime} \mathrm{N}, 130^{\circ} 40^{\prime} \mathrm{E}\right) ; 19-22\left(33^{\circ} 25^{\prime} \mathrm{N}, 130^{\circ} 40^{\prime} \mathrm{E}\right) ; 2 \mathrm{O}-22\left(33^{\circ} 25^{\prime} \mathrm{N}, 130^{\circ} 40^{\prime}\right.$ E); 21-19 ( $\left.33^{\circ} 25^{\prime} \mathrm{N}, 130^{\circ} 40^{\prime} \mathrm{E}\right) ; 22-14\left(35^{\circ} \mathrm{O} 5^{\prime} \mathrm{N}, 132^{\circ} 47^{\prime} \mathrm{E}\right) ; 23-6\left(35^{\circ} 35^{\prime} \mathrm{N}, 136^{\circ} 27^{\prime}\right.$ E); $24-6\left(35^{\circ} 35^{\prime} \mathrm{N}, 136^{\circ} 27^{\prime} \mathrm{E}\right) ; 25^{-10}\left(35^{\circ} 35^{\prime} \mathrm{N}, 136^{\circ} 27^{\prime} \mathrm{E}\right) ; 26-10\left(35^{\circ} 35^{\prime} \mathrm{N}, 136^{\circ} 27^{\prime}\right.$ E); $27-15\left(35^{\circ} 35^{\prime} \mathrm{N}, 136^{\circ} 27^{\prime} \mathrm{E}\right) ; 28-10\left(35^{\circ} 35^{\prime} \mathrm{N}, 136^{\circ} 27^{\prime} \mathrm{E}\right) ; 29-10\left(35^{\circ} 35^{\prime} \mathrm{N}\right.$, $\left.136^{\circ} 27^{\prime} \mathrm{E}\right) ; 30-8\left(35^{\circ} 35^{\prime} \mathrm{N}, 136^{\circ} 27^{\prime} \mathrm{E}\right) ; 31-9\left(35^{\circ} 35^{\prime} \mathrm{N}, 136^{\circ} 27^{\prime} \mathrm{E}\right) ; 32-24\left(35^{\circ} 35^{\prime} \mathrm{N}\right.$, $\left.136^{\circ} 27^{\prime} \mathrm{E}\right) ; 33-24\left(35^{\circ} 35^{\prime} \mathrm{N}, 136^{\circ} 27^{\prime} \mathrm{E}\right) ; 34^{-19}\left(35^{\circ} 35^{\prime} \mathrm{N}, 136^{\circ} 27^{\prime} \mathrm{E}\right) ; 35^{-6}\left(35^{\circ} 35^{\prime} \mathrm{N}\right.$, $\left.136^{\circ} 27^{\prime} \mathrm{E}\right) ; 36-6\left(35^{\circ} 35^{\prime} \mathrm{N}, 136^{\circ} 27^{\prime} \mathrm{E}\right) ; 37-11\left(35^{\circ} 35^{\prime} \mathrm{N}, 136^{\circ} 27^{\prime} \mathrm{E}\right) ; 38-25\left(35^{\circ} 35^{\prime} \mathrm{N}\right.$, $\left.136^{\circ} 27^{\prime} \mathrm{E}\right) ; 39^{-25}\left(35^{\circ} 35^{\prime} \mathrm{N}, 136^{\circ} 27^{\prime} \mathrm{E}\right) ; 40-1\left(36^{\circ} 46^{\prime} \mathrm{N}, 139^{\circ} 14^{\prime} \mathrm{E}\right) ; 41-6\left(36^{\circ} 46^{\prime} \mathrm{N}\right.$, $\left.139^{\circ} 14^{\prime} \mathrm{E}\right) ; 42^{-12}\left(36^{\circ} 46^{\prime} \mathrm{N}, 139^{\circ} 14^{\prime} \mathrm{E}\right) ; 43^{-12}\left(36^{\circ} 46^{\prime} \mathrm{N}, 139^{\circ} 14^{\prime} \mathrm{E}\right) ; 44^{-18}\left(36^{\circ} 46^{\prime}\right.$ $\left.\mathrm{N}, 139^{\circ} 14^{\prime} \mathrm{E}\right) ; 45^{-18}\left(36^{\circ} 46^{\prime} \mathrm{N}, 139^{\circ} 14^{\prime} \mathrm{E}\right) ; 46-18\left(36^{\circ} 46^{\prime} \mathrm{N}, 139^{\circ} 14^{\prime} \mathrm{E}\right) ; 47-18$ $\left(36^{\circ} 46^{\prime} \mathrm{N}, 139^{\circ} 14^{\prime} \mathrm{E}\right) ; 48-1\left(36^{\circ} 46^{\prime} \mathrm{N}, 139^{\circ} 14^{\prime} \mathrm{E}\right) ; 49^{-2}\left(36^{\circ} 46^{\prime} \mathrm{N}, 139^{\circ} 14^{\prime} \mathrm{E}\right) ; 50-20$ $\left(36^{\circ} 46^{\prime} \mathrm{N}, 139^{\circ} 14^{\prime} \mathrm{E}\right) ; 51-2\left(36^{\circ} 46^{\prime} \mathrm{N}, 139^{\circ} 14^{\prime} \mathrm{E}\right) ; 52-1\left(36^{\circ} 46^{\prime} \mathrm{N}, 139^{\circ} 14^{\prime} \mathrm{E}\right) ; 53^{-1}$ $\left(36^{\circ} 46^{\prime} \mathrm{N}, 139^{\circ} 14^{\prime} \mathrm{E}\right) ; 54-3\left(36^{\circ} 46^{\prime} \mathrm{N}, 139^{\circ} 14^{\prime} \mathrm{E}\right) ; 55^{-3}\left(36^{\circ} 46^{\prime} \mathrm{N}, 139^{\circ} 14^{\prime} \mathrm{E}\right) ; 56-8$ $\left(35^{\circ} 33^{\prime} \mathrm{N}, 136^{\circ} 12^{\prime} \mathrm{E}\right) ; 57-8\left(35^{\circ} 33^{\prime} \mathrm{N}, 136^{\circ} 12^{\prime} \mathrm{E}\right) ; 58-8$ ( $\left.35^{\circ} 33^{\prime} \mathrm{N}, 136^{\circ} 12^{\prime} \mathrm{E}\right) ; 59-11$ $\left(35^{\circ} 33^{\prime} \mathrm{N}, 136^{\circ} 12^{\prime} \mathrm{E}\right) ; 60-12\left(35^{\circ} 33^{\prime} \mathrm{N}, 136^{\circ} 12^{\prime} \mathrm{E}\right) ; 61-12\left(35^{\circ} 33^{\prime} \mathrm{N}, 136^{\circ} 12^{\prime} \mathrm{E}\right)$; $62-26\left(35^{\circ} 33^{\prime} \mathrm{N}, 136^{\circ} 12^{\prime} \mathrm{E}\right) ; 63-12\left(35^{\circ} 33^{\prime} \mathrm{N}, 136^{\circ} 12^{\prime} \mathrm{E}\right) ; 64-4\left(36^{\circ} 42^{\prime} \mathrm{N}, 139^{\circ} 13^{\prime} \mathrm{E}\right) ;$ 65-4 ( $\left.36^{\circ} 42^{\prime} \mathrm{N}, 139^{\circ} 13^{\prime} \mathrm{E}\right) ; 66-2\left(36^{\circ} 42^{\prime} \mathrm{N}, 139^{\circ} 13^{\prime} \mathrm{E}\right) ; 67-2\left(36^{\circ} 42^{\prime} \mathrm{N}, 139^{\circ} 13^{\prime} \mathrm{E}\right)$; 68-5 ( $\left.36^{\circ} 42^{\prime} \mathrm{N}, 139^{\circ} 13^{\prime} \mathrm{E}\right) ; 69-12\left(35^{\circ} 56^{\prime} \mathrm{N}, 137^{\circ} 47^{\prime} \mathrm{E}\right) ; 70-7\left(35^{\circ} 56^{\prime} \mathrm{N}, 137^{\circ} 47^{\prime} \mathrm{E}\right)$; $71-7\left(35^{\circ} 56^{\prime} \mathrm{N}, 137^{\circ} 47^{\prime} \mathrm{E}\right) ; 72-7\left(35^{\circ} 56^{\prime} \mathrm{N}, 137^{\circ} 47^{\prime} \mathrm{E}\right) ; 73-7\left(35^{\circ} 48^{\prime} \mathrm{N}, 138^{\circ} \mathrm{O} 5^{\prime} \mathrm{E}\right) ;$ 74-7 ( $\left.35^{\circ} 48^{\prime} \mathrm{N}, 138^{\circ} \mathrm{O}^{\prime} \mathrm{E}\right) ; 75^{-6}\left(35^{\circ} 48^{\prime} \mathrm{N}, 138^{\circ} \mathrm{O}^{\prime} \mathrm{E}\right) ; 76-6\left(36^{\circ} 34^{\prime} \mathrm{N}, 138^{\circ} 5 \mathrm{O}^{\prime} \mathrm{E}\right)$; $77-2\left(36^{\circ} 34^{\prime} \mathrm{N}, 138^{\circ} 50^{\prime} \mathrm{E}\right) ; 78-1\left(36^{\circ} 34^{\prime} \mathrm{N}, 138^{\circ} 50^{\prime} \mathrm{E}\right) ; 79-14\left(33^{\circ} 23^{\prime} \mathrm{N}, 132^{\circ} 39^{\prime} \mathrm{E}\right) ;$ $8 \mathrm{O}-2\left(36^{\circ} 27^{\prime} \mathrm{N}, 137^{\circ} \mathrm{O} 2^{\prime} \mathrm{E}\right) ; 81-4\left(36^{\circ} 27^{\prime} \mathrm{N}, 137^{\circ} \mathrm{O} 2^{\prime} \mathrm{E}\right) ; 82-6\left(36^{\circ} 27^{\prime} \mathrm{N}, 137^{\circ} \mathrm{O} 2^{\prime} \mathrm{E}\right) ;$ 83-10 ( $\left.36^{\circ} 27^{\prime} \mathrm{N}, 137^{\circ} \mathrm{O} 2^{\prime} \mathrm{E}\right) ; 84-5$ ( $\left.43^{\circ} 3 \mathrm{O}^{\prime} \mathrm{N}, 142^{\circ} 3 \mathrm{O}^{\prime} \mathrm{E}\right) ; 85-6\left(35^{\circ} \mathrm{O} 5^{\prime} \mathrm{N}, 137^{\circ} 49^{\prime} \mathrm{E}\right)$; 86-16 ( $\left.39^{\circ} 22^{\prime} \mathrm{N}, 141^{\circ} 54^{\prime} \mathrm{E}\right) ; 87-3\left(41^{\circ} 26^{\prime} \mathrm{N}, 140^{\circ} 52^{\prime} \mathrm{E}\right) ; 88-23\left(41^{\circ} 24^{\prime} \mathrm{N}, 141^{\circ} 10^{\prime} \mathrm{E}\right) ;$ 89-2 ( $\left.36^{\circ} 35^{\prime} \mathrm{N}, 137^{\circ} 12^{\prime} \mathrm{E}\right) ; 90-1\left(36^{\circ} 35^{\prime} \mathrm{N}, 137^{\circ} 12^{\prime} \mathrm{E}\right) ; 91-8\left(33^{\circ} 55^{\prime} \mathrm{N}, 135^{\circ} 30^{\prime} \mathrm{E}\right)$; 92-25 (34 $\left.46^{\prime} \mathrm{N}, 136^{\circ} 18^{\prime} \mathrm{E}\right) ; 93-26\left(35^{\circ} 15^{\prime} \mathrm{N}, 135^{\circ} 28^{\prime} \mathrm{E}\right)$.

\section{Acknowledgements}

We thank the River Bureau, the Ministry of Land, Infrastructure and Transport, and the Incorporated Administrative Agency, Japan Water Agency (the former Water Resources Development Public Corporation) for providing most of the samples used in this study. We are also grateful to O. Nemoto, G. Sakamoto, H. Sakai and A. Uemura, and to Dr T. Maeda (Research Institute for Environmental Sciences and Public Health of Iwate Prefecture), as well as the Kushiro Zoo and the Wildlife Preservation Bureau of Hokkaido, Corp., for providing samples. We thank the Kyoto Municipal Zoo for providing the blood samples used for determining the complete mtDNA sequence. The very useful comments by Dr V. Nijman and an anonymous 
reviewer are greatly appreciated. This study was entrusted by the Japan Water Agency and was supported by a Grant-in-Aid for Scientific Research by the Ministry of Education, Culture, Sports, Science and Technology.

\section{References}

Ali, S. and Ripley, S. D. (1978) Handbook of the Birds of India and Pakistan Together with Those of Bangladesh, Nepal, Bhutan and Sri Lanka. Second Edition. Vol. 1. Delhi: Oxford University Press.

Austin, O. L., Jr (1948) The Birds of Korea. Bull. Mus. Comp. Zool. 101: 1-301.

Baba, Y., Fuzimaki, Y. and Koike, H. (1999) Genetic diversity and gene flow of the hazel grouse Bonasa bonasia in Japan. Jpn. J. Ornithol. 48: 47 6o. (In Japanese.)

Baker, A. J. and Marshall, H. D. (1997) Mitochondrial control region sequences as tools for understanding evolution. Pp. 51-82 in D. P. Mindell, ed. Avian Molecular Evolution and Systematics. San Diego and London: Academic Press.

van Balen, S., Nijman, V. and Sözer, R. (2001) Conservation of the endemic Javan hawk-eagle Spizaetus bartelsi Stresemann, 1924 (Aves: Falconiformes): density, age-structure and population numbers. Contrib. Zool. 70: 161-173.

Brazil, M. A. (1991) The Birds of Japan. London: Christopher Helm.

van den Bussche, R. A., Hoofer, S., Wiedenfeld, D. A., Wolfe, D. H. and Sherrod, S. K. (2003) Genetic variation within and among fragmented populations of lesser prairie-chickens (Tympanuchus pallidicinctus). Mol. Ecol. 12: 675-683.

Clement, M., Posada, D. and Crandall, K. A. (2000) TCS: a computer program to estimate gene genealogies. Mol. Ecol. 9: 1657-166o.

Committee for Check-List of Japanese Birds (2000) Check-List of Japanese Birds. Sixth edition. Obihiro: The Ornithological Society of Japan.

Grimmett, R., Inskipp, C. and Inskipp, T. (1998) Birds of the Indian Subcontinent. London: Christopher Helm.

Haring, E., Riesing, M. J., Pinsker, W. and Gamauf, A. (1999) Evolution of a pseudo-control region in the mitochondrial genome of Palearctic buzzards (genus Buteo). J. Zool. Syst. Evol. Res. 37: 185-194.

Hasegawa, O., Takada, S., Yoshida, M. C. and Abe, S. (1999) Variation of mitochondrial control region sequences in three crane species: the red-crowned crane Grus japonensis, the common crane G. grus and the hooded crane G. monacha. Zool. Sci. 16: 685-692.

Inoue, T. (2000) Results of recent research on the biology of the mountain hawk eagle (Spizaetus nipalensis orientalis) in the Suzuka mountains. Pp. 189-194 in The Committee for the Symposium on Raptors of South-East Asia, ed. Asian Raptor Research \& Conservation: The First Symposium on Raptors of South-Ear Asia: Proceedings. Yasu: The Committee for the Symposium on Raptors of South-East Asia. (In Japanese.)

Inskipp, C. and Inskipp, T. (1991) A Guide to the Birds of Nepal. Second Edition. London: Christopher Helm.

Kahn, N. W., Braun, C. E., Young, J. R., Wood, S., Mata, D. R. and Quinn, T. W. (1999) Molecular analysis of genetic variation among large- and small-bodied sage grouse using mitochondrial control-region sequences. Auk 116: 819-824.

Marshall, H. D. and Baker, A. J. (1997) Structural conservation and variation in the mitochondrial control region of fringilline finches (Fringilla spp.) and the Greenfinch (Carduelis chloris). Mol. Biol. Evol. 14: 173-184.

Martínez-Cruz, B., Godoy, J. A. and Negro, J. J. (2004) Population genetics after fragmentation: the case of the endangered Spanish imperial eagle (Aquila adalberti). Mol. Ecol. 13: $2243-2255$. 
Masuda, R., Noro, M., Kurose, N., Nishida-Umehara, C., Takechi, H., Yamazaki, T., Kosuge, M. and Yoshida, M. C. (1998) Genetic characteristics of endangered Japanese golden eagles (Aquila chrysaetos japonica) based on mitochondrial DNA D-loop sequences and karyotypes. Zoo Biol. 17:111-121.

Mindell, D. P., Sorenson, M. D. and Dimcheff, D. E. (1998) Multiple independent origins of mitochondrial gene order in birds. Proc. Natl. Acad. Sci. USA 95: 10693-10697.

Ministry of the Environment (2002) Threatened Wildlife of Japan: Red Data Book. Second edition. Vol. 2: Aves. Tokyo: Japan Wildlife Research Center.

Morimoto, S. and Iida, T. (1992) Ecology and preservation of Hodgson's hawk-eagles. Strix 11: 59-90. (In Japanese.)

Morioka, T., Yamagata, N., Kanouchi, T. and Kawata, T. (1995) The Birds of Prey in Japan. Tokyo: Bun-ichi Sôgô Shuppan. (In Japanese.)

Moum, T. and Árnason, E. (2001) Genetic diversity and population history of two related seabird species based on mitochondrial DNA control region sequences. Mol. Ecol. 10: 2463-2478.

Murate, T. (2000) The home range and habitat use of sub-adults of the Japanese Mountain Hawk-eagle (Spizaetus nipalensis) in Japan. Pp. 155-159 in D. M. Prawiradilaga, ed. Proceedings Asian Raptor Research \& Conservation: The Second Symposium on Raptor of Asia. Cibinong: Indonesian Committee for the Second Symposium of Asian Raptor Research and Conservation.

Nei, M. (1973) Analysis of gene diversity in subdivided populations. Proc. Natl. Acad. Sci. USA 70: $3321-3323$.

Nei, M. and Tajima, F. (1981) DNA polymorphism detectable by restriction endonucleases. Genetics 97: 145-163.

Nijman, V. and van Balen, S. (2003) Wandering stars: age-related habitat use and dispersal of Javan Hawk-eagles (Spizaetus bartelsi). J. Ornithol. 144: 451-458.

Posada, D., Crandall, K. A. and Templeton, A. R. (2000) GeoDis: a program for the cladistic nested analysis of the geographical distribution of genetic haplotypes. Mol. Ecol. 9: 487-488.

Preleuthner, M. and Gamauf, A. (1998) A possible new subspecies of the Philippine hawk-eagle (Spizaëtus philippensis) and its future prospects. J. Raptor Res. 32: 126-135.

Primack, B. P. and Kobori, H. (1997) A Primer of Conservation Biology (revised version in Japanese). Tokyo: Bun-ichi Sougou Shuppan.

Rogers, A. R. and Harpending, H. (1992) Population growth waves in the distribution of pairwise genetic differences. Mol. Biol. Evol. 9: 552-569.

Schneider, S. and Excoffier, L. (1999) Estimation of past demographic parameters from the distribution of pairwise differences when the mutation rates vary among sites: application to human mitochondrial DNA. Genetics 152: 1079-1089.

Schneider, S., Roessli, D. and Excoffier, L. (2000) Arlequin: a software for population genetics data analysis. Version 2.00o. Genetics and Biometry Laboratory, Department of Anthropology, University of Geneva.

Templeton, A. R. (1998) Nested clade analyses of phylogeographic data: testing hypotheses about gene flow and population history. Mol. Ecol. 7: 381-397.

Templeton, A. R., Boerwinkle, E. and Sing, C. F. (1987) A cladistic analysis of phenotypic associations with haplotypes inferred from restriction endonuclease mapping. I. Basic theory and an analysis of alcohol dehydrogenase activity in Drosophila. Genetics 117: 343-351.

Templeton, A. R., Crandall, K. A. and Sing, C. F. (1992) A cladistic analysis of phenotypic associations with haplotypes inferred from restriction endonuclease mapping and DNA sequence data. III. Cladogram estimation. Genetics 132: 619-633.

Templeton, A. R., Routman, E. and Phillips, C. A. (1995) Separating population structure from population history: a cladistic analysis of the geographical distribution of mitochondrial DNA haplotypes in the tiger salamander, Ambystoma tigrinum. Genetics 140: 767-782.

Uimaniemi, L., Orell, M., Mönkkönen, M., Huhta, E., Jokimäki, J. and Lumme, J. (2000) Genetic diversity in the Siberian jay Perisoreus infaustus in fragmented old-growth forests of Fennoscandia. Ecography 23: 669-677. 
Wenink, P. W., Baker, A. J. and Tilanus, M. G. (1994) Mitochondrial control-region sequences in two shorebird species, the turnstone and the dunlin, and their utility in population genetic studies. Mol. Biol. Evol. 11: 22-31.

Yamamoto, Y., Murata, K., Matsuda, H., Hosoda, T., Tamura, K. and Furuyama, J. (2000) Determination of the complete nucleotide sequence and haplotypes in the D-loop region of the mitochondrial genome in the oriental white stork, Ciconia boyciana. Genes Genet. Syst. 75: $25-32$.

Yamazaki, T. (2000) Ecological research and its relationship to the conservation programme of the Golden Eagle and the Japanese Mountain Hawk-Eagle. Pp. 195-210 in The Committee for the Symposium on Raptors of South-East Asia, ed. Asian Raptor Research \& Conservation: The First Symposium on Raptors of South-Ear Asia: Proceedings. Yasu: The Committee for the Symposium on Raptors of South-East Asia.

SHIGEKI ASAI* and SATOSHI YAMAGISHI

Yamashina Institute for Ornithology, 115 Konoyama, Abiko, Chiba 270-1145, Japan. E-mail: asai@yamashina.or.jp

YOSHIHIRO YAMAMOTO

Department of Genetics, Hyogo College of Medicine, 1-1 Mukogawa-cho, Nishinomiya, Hyogo 663-8501, Japan.

${ }^{*}$ Author to whom correspondence should be addressed.

Received 6 December 2004; revision accepted 23 June 2005 